\title{
GENETIC CHARACTERIZATION OF TUNISIAN LIME GENOTYPES USING POMOLOGICAL TRAITS
}

\author{
Olfa SADDOUD DEBBABI*1‡, Selma Ben ABDELAALI ${ }^{2 \ddagger}$, Rym BOUHLAL ${ }^{3}$, \\ Sabrine ZNEIDI ${ }^{1}$, Nasr Ben ABDELAALI ${ }^{3}$, Massaoud MARS ${ }^{2}$ \\ ${ }^{1}$ Banque Nationale de Gènes, Boulevard du Leader Yesser Arafet, Charguia 1, Tunis, Tunisia \\ ${ }^{2}$ Institut Supérieur Agronomique de Chott-Mariem, IRESA, Université de Sousse, Tunisia \\ ${ }^{3}$ Institut National de la Recherche Agronomique de Tunisie, Tunisia
}

Received: October 2019; Accepted: March 2020

\begin{abstract}
Citrus genus includes a wide number of species that have been long cultivated and well adapted in Tunisia. It is represented by small number of plantations and considered as underutilized in Tunisia. Our goal was to genetically characterize Tunisian lime genotypes to obtain data useful for gene conservation and breeding purposes. The survey of genotypes was conducted in the Cap Bon region, where citrus cultivation is the most spread. Sixteen quantitative and 19 qualitative parameters were evaluated. The observed accessions belonged to three different species: Citrus limetta, Citrus latifolia (limes Byrsa), and Citrus limettioides (limes of Palestine) according to Tanaka classification. Principal component analysis confirmed these classifications. Four-cell analysis (FCA) was used to determine the most threatened genotypes. Quantitative traits were evaluated and allowed the discrimination between genotypes. Many quantitative traits of fruit and juice were highly positively and significantly correlated. Phenotypic diversity was determined using Shannon-Wiener diversity index (H'). The highest value of diversity index was observed for both vesicle thickness and thickness of segment walls $\left(\mathrm{H}^{\prime}=0.98\right)$. Intermediate values were observed for both fruit axis $\left(H^{\prime}=0.49\right)$ and pulp firmness $\left(H^{\prime}=0.43\right)$. However, fruit shape $\left(H^{\prime}=0.24\right)$, shape of fruit apex $\left(\mathrm{H}^{\prime}=0.24\right)$, and vesicle length $\left(\mathrm{H}^{\prime}=0.33\right)$ presented the lowest values of diversity index. Current findings will be useful to conserve threatened genotypes ex situ and on farm and also will guide strategic conservation on Citrus genetic resources for future breeding programs.
\end{abstract}

Key words: diversity, genetic resources, limes, pomology

\section{INTRODUCTION}

Citrus (Rutaceae family) is one of the most important and ancient crop species domesticated by humans (Krueger \& Navarro 2007). Citrus taxonomy and phylogeny are very complicated, controversial, and confusing mainly due to sexual compatibility between Citrus and related genera, the high frequency of bud mutations, the long history of cultivation, and wide dispersion (Nicolosi et al. 2000). The taxonomy of the genus Citrus is controversial as two systems of classification were suggested: Swingle and Reece (1967) distinguished 156 species, whereas Tanaka (1977) only 16 species. It is believed that some Citrus types, including citrons, sour oranges, and lemons, were spread slowly from 500 to $1300 \mathrm{AD}$ through wide areas, including Europe, by successive waves of invaders and travelers of Muslim armies, Arab traders, Crusaders, and others moving along trade routes from other populations to Europe (Moore 2001). Lemon, lime, sour orange, sweet orange, grapefruit, and other edible fruits are apomictically perpetuated biotypes with probable hybrid origin (Kumar et al. 2010).

Lime is a traditional crop in South Asia and the Middle East and comprises a varied group of types of sour and sweet cultivars, different from one to another with distinct fruit characteristics (Nicolosi et al. 2000). Limes hybridize well with other Citrus species. 
Hybrids could be between lime and lemon or lime and kumquat (Scora 1975), or a tri-hybrid species of citron, pummelo, and Microcitrus (Barrett \& Rhodes 1976). In Tunisia, Citrus is one of the most economically important crops. The weather and soil conditions in Tunisia, particularly in the Cap Bon region, are suitable for Citrus production. Currently in Tunisia Citrus plantations extend more than $22,000 \mathrm{ha}$, and fruit production in the last 5 years increased to 323,000 tones (DGPA 2016). Although limes are classified as a major fruit crop (Mabberley 2008), it is sporadically cultivated in Tunisia. Price of fruit is very high compared with those of sweet orange. Lime is facing different increasing constraints, such as water availability and quality, weather conditions, expansion of diseases, necessity to change the old farming techniques, and urbanization. All these restrictions pose a threat to genetic resources of lime genetic resources in Tunisia. Citrus germplasm is very diverse with many autochthonous cultivars, and it is imperative to implement a strategy for the conservation of genetic resources. For the first time in Tunisia, collecting missions were realized in order to identify and characterize limes' accessions. In this study, pomological traits were evaluated to determine the genetic diversity of lime. Data collected allowed the establishment of passport data. These findings will enhance both ex situ and on farm genetic conservation program of Citrus germplasm.

\section{MATERIALS AND METHODS}

\section{Plant material}

Accessions were collected in 2013-2014 and re-collected in 2014-2015 (Table 1) throughout the Cap Bon Nord region east of Tunisia, where citrus cultivation is most widespread. Acquisitions were carried out among a wide range of stakeholders and with the presence of local governmental agencies both in farms and ex situ collections. During the collecting missions, we visited old orchards where limes were cultivated for many decades. Farmers and technical staffs from regional authorities confirmed the names of genotypes. Identification of species was performed with the help of Blondel (1978) classification. Four-cell analysis (FCA)

The FCA was used to classify the three species under consideration based on the size of the cultivation area and on the number of households, as described by Sthapit et al. (2012).

\section{Pomological characterization}

The fully ripe fruits were taken from the four directions of the tree and from the interior and exterior layers of the canopy at the rate of 30 fruits per tree. These fruits were divided into 3 batches of 10 fruits to analyze the quantitative traits (Table 2) and the juice parameters (Table 3 ). For pomological characterization, analysis has been performed separately for each growing season. Sixteen quantitative traits, including seven parameters dealing with juice description, were measured (Table 4) and correlations among those traits were calculated (Table 5). Nineteen qualitative characters (Table 6) were chosen based on Citrus descriptors (IPGRI 1999). Fresh juice was obtained using a citrus press (Santos Classic N`11, Lyon, France). Subsequently, the juice was filtered through a 1-mm mesh sieve; weighed and volume was measured in a burette. Density was estimated in a sample of $100 \mathrm{ml}$ of juice. Total soluble solids (TSS) content was determined by direct readings on a hand-held refractometer (Toledo, $30 \mathrm{PX}$ ) calibrated before use with distilled water. The $\mathrm{pH}$ was measured using a pH meter (Toledo, S22) previously calibrated. The titratable acidity (TA) of the juice was evaluated by the determination of citric acid by titration with a $\mathrm{NaOH}$ solution $(0.1 \mathrm{~N})$. The determination of vitamin $\mathrm{C}$ was carried out by titration with iodine solution. Data were obtained in triplicate.

\section{Data analysis}

For quantitative traits, all analyses were performed using SAS software (version 6.07, 1990). Descriptive statistics were performed and presented as minimum, maximum, mean standard deviation, and coefficient of variation (CV). One-way analysis of variance (ANOVA) was used, and data are presented as mean \pm standard deviation (SD). Pearson index was calculated for quantitative traits. Principal component analysis (PCA) was carried out to examine the distribution of genotypes in the first plan of PCA for quantitative parameters. For qualitative data, frequency distributions were computed.

The numbers of phenotypic classes for qualitative parameters that differed for each trait were used to estimate the Shannon-Wiener diversity index (H'). It was used to characterize the phenotypic frequencies of the traits and was defined as $\mathrm{H}=\sum_{i=1}^{n} p i \ln p i$, 
where $\mathrm{n}$ is the number of phenotypic classes for a character and $p i$ is the proportion of the total number of entries in the $i$ th class. Each value of $\mathrm{H}$ was standardized by conversion to a relative phenotypic diversity index (H') by division by $\mathrm{H}_{\max }=\ln (\mathrm{n})$ in order to express the values of $\mathrm{H}^{\prime}\left(\mathrm{H} / \mathrm{H}_{\max }\right)$ in the range of $0-1$ (indicating the absence of diversity and maximum of diversity, respectively). The diversity index was classified as high $\left(\mathrm{H}^{\prime} \geq 0.6\right)$, intermediate $\left(0.40 \leq \mathrm{H}^{\prime} \leq 0.60\right)$, or low $\left(0.1 \leq \mathrm{H}^{\prime} \leq 0.40\right)$, as described by Eticha et al. (2005) and Mengistu et al. (2015).

\section{RESULTS AND DISCUSSION}

On the basis of pomological traits, we have described the characteristics and the variability of each genotype originating from different orchards. Measurements for both fruit and juice traits are presented in Tables 2 and 3, respectively. LimePal2 represented the highest value of fruit weight, diameter, length, width of skin, and width of epicarp at equatorial area. Lime10 also exhibited high caliber of fruit. The smallest fruit attributes were those of Lime17. LimePal1 had by far the most important number of segments. All genotypes held seeds varying in number from 1.2 to 5.4. The diameter of axis varied widely among the different genotypes (Table 2). Concerning juice attributes, LimPal2 and Lime8 were the juiciest. The sweetest juice was that of LimePal1, LimePal2, and Lime17. Values of $\mathrm{pH}$ were the highest for Lime13, Lime16, Lime17, and Lime3. All genotypes exhibited high content of vitamin C. Concentrations varied from more than $48 \mathrm{mg} \cdot 100 \mathrm{mg}^{-1}$ (Table 3) for genotypes LimePall and Lime 8 to about $26 \mathrm{mg} \cdot 100 \mathrm{mg}^{-1}$ for Lime20 and Lime4. The recorded data were subjected to statistical analyses as described in Material and Methods that showed the utility of both quantitative and qualitative phenotypic characterizations for the identification of genetic resources of limes.

\section{Species classification and estimation of genetic} resources status

The participatory FCA was used, while regional agricultural authorities and the farmers were interviewed. It allowed categorizing $C$. limetta as a threatened species. Although many householders cultivated this species, it was propagated in small area. C. latifolia and C. limettioides were classified as rare species because they were cultivated in small area and by few householders (Fig. 1). Thus, special attention must be paid to these species in order to conserve them and encourage their dissemination. The most cultivated species was $C$. limetta in contrast to C. latifolia, which is the least cultivated (Table 1). Accessions from different species showed a wide range of variability for all the pomological traits studied. According to a recent research, Curk et al. (2016) have elucidated the origins of limes and lemons based on cytoplasmic and nuclear markers. The survey highlighted that all limes and lemons descend from Citrus medica as the direct male parent in combination with Citrus aurantium for $C$. limetta and a hybrid (Citrus maxima $\times$ Citrus reticulata) for C. limettioides. Among triploid limes, C. latifolia accessions Persian lime types result from the fertilization of a haploid ovule of Citrus limon by a diploid gamete of Citrus aurantifolia. As limes and lemons were vegetatively propagated by apomixes and horticultural practices, the intra-subgroup phenotypic diversity results from asexual variations (Curk et al. 2016). Two classifications of limes have been reported: lime of Pearse known as $C$. aurantifolia hybrid by Swingle and Reece (1967) and C. latifolia Tan. by Tanaka (1977). Instead, sweet lime of Tunisia is classified as C.limon (L.) Burm. by Swingle and Reece (1967) and C. limetta Risso by Tanaka (1977). The results can be useful for both selection of cultivars and breeding programs aiming the improvement of fruit quality. Snoussi et al. (2012) revealed that both sexual and asexual reproductions of limes cultivated in Tunisia contributed to their genetic diversity.

\begin{tabular}{|c|c|}
\hline $\begin{array}{l}\text { Large area } \\
\text { Many House }\end{array}$ & $\begin{array}{l}\text { Large area } \\
\text { Few House }\end{array}$ \\
\hline Common & Threatene \\
\hline Small area & Small area \\
\hline Many House & Few House \\
\hline \multirow[t]{2}{*}{ C. limetta } & C. Latifolia \\
\hline & C. Limettiondes \\
\hline Threatened & Rare \\
\hline
\end{tabular}

Fig. 1. Classification of limes species in Tunisia following FCA 
Table 1. List of species, genotypes studied, abbreviations, acquisition date and accession numbers

\begin{tabular}{lccc}
\hline \multicolumn{1}{c}{ Species } & Abbreviations & Date of first acquisition & Accession ID \\
\hline Citrus limettioides & LimePal 1 & $23 / 01 / 2014$ & NGBTUN 757 ARB \\
& LimePal 2 & $10 / 02 / 2014$ & NGBTUN 992 ARB \\
\hline Citrus latifolia & LimeBirs & $04 / 02 / 2014$ & NGBTUN 782 ARB \\
\hline Lime1 & $10 / 02 / 2014$ & NGBTUN 756 ARB \\
& Lime2 & $23 / 01 / 2014$ & NGBTUN 788 ARB \\
& Lime3 & $23 / 01 / 2014$ & NGBTUN 793 ARB \\
& Lime4 & $23 / 01 / 2014$ & NGBTUN 794 ARB \\
& Lime5 & $23 / 01 / 2014$ & NGBTUN 795 ARB \\
Lime6 & $23 / 01 / 2014$ & NGBTUN 797 ARB \\
& Lime7 & $23 / 01 / 2014$ & NGBTUN 798 ARB \\
& Lime8 & $04 / 02 / 2014$ & NGBTUN 800 ARB \\
& Lime9 & $15 / 01 / 2014$ & NGBTUN 994 ARB \\
Lime10 & $15 / 01 / 2014$ & NGBTUN 823 ARB \\
& Lime11 & $15 / 01 / 2014$ & NGBTUN 1033 ARB \\
& Lime12 & $28 / 04 / 2014$ & NGBTUN 803 ARB \\
& Lime13 & $30 / 01 / 2014$ & NGBTUN 808 ARB \\
& Lime14 & $30 / 01 / 2014$ & NGBTUN 812 ARB \\
& Lime15 & $30 / 01 / 2014$ & NGBTUN 815 ARB \\
& Lime16 & $10 / 02 / 2014$ & NGBTUN 824 ARB \\
& Lime17 & $10 / 02 / 2014$ & NGBTUN 759 ARB \\
& Lime18 & $10 / 02 / 2014$ & NGBTUN 758 ARB \\
Lime19 & $30 / 01 / 2014$ & NGBTUN 993 ARB
\end{tabular}

Table 2. Mean values and significance degree of differences between lime genotypes for fruit characteristics

\begin{tabular}{|c|c|c|c|c|c|c|c|c|c|}
\hline $\begin{array}{l}\text { Geno- } \\
\text { types }\end{array}$ & $\begin{array}{l}\text { Weight } \\
\text { (g) }\end{array}$ & $\begin{array}{l}\text { Diameter } \\
(\mathrm{mm})\end{array}$ & $\begin{array}{l}\text { Length } \\
(\mathrm{mm})\end{array}$ & $\begin{array}{c}\text { Width } \\
\text { of skin } \\
(\mathrm{mm})\end{array}$ & $\begin{array}{l}\text { Width of epicarp } \\
\text { at equatorial plane } \\
(\mathrm{mm}) \\
\end{array}$ & $\begin{array}{c}\text { Mesocarp } \\
\text { thickness } \\
(\mathrm{mm})\end{array}$ & $\begin{array}{c}\text { Number } \\
\text { of seg- } \\
\text { ment } \\
\end{array}$ & $\begin{array}{l}\text { Number } \\
\text { of seeds }\end{array}$ & $\begin{array}{c}\text { Diameter } \\
\text { of axis } \\
(\mathrm{mm}) \\
\end{array}$ \\
\hline ePal 1 & $69.0 \pm 30 \mathrm{e}$ & & & $3.16 \pm 0.5 b c$ & $1.46 \pm 0.3 \mathrm{~d}$ & $.5 \mathrm{ab}$ & $16.46 \pm 4 \mathrm{a}$ & $1.93 \pm 0.5 \mathrm{de}$ & $6 \pm 1 \mathrm{de}$ \\
\hline ePal 2 & $157.9 \pm 34 \mathrm{a}$ & $65 \pm 1.3 \mathrm{a}$ & $9 \pm 0.7 \mathrm{a}$ & $4 \pm 1 \mathrm{a}$ & $2.75 \pm$ & $1.33=$ & $10.26 \pm 4 b$ & $3.8 \pm 0.7 \mathrm{c}$ & $13.4 \pm 3 \mathrm{a}$ \\
\hline nebirs & $87.1 \pm 34 \mathrm{~d}$ & $60 \pm 1 \mathrm{a}$ & $50 \pm 0.6 \mathrm{~cd}$ & $3.09 \pm 0.5 \mathrm{c}$ & $5 \mathrm{c}$ & $1.14 \pm$ & $8.6 \pm 3 \mathrm{~cd}$ & $2.26 \pm 0.6 \mathrm{~d}$ & $8.92 \pm 3 b$ \\
\hline 1 & $74.3 \pm 23 \mathrm{ef}$ & $0.4 \mathrm{~d}$ & $\mathrm{~d}$ & 3. & $4 c$ & 1.38 & $8.46 \pm 3 \mathrm{~cd}$ & $2.46 \pm 0.6 \mathrm{~d}$ & $8 \pm 3 b c$ \\
\hline Lime2 & $77 \pm 17 \mathrm{e}$ & $50 \pm$ & 5 & $3 \pm 0$ & & $1 \pm 0.2 \mathrm{~d}$ & $9 \pm 3 c$ & & $9.4 \pm 3 b$ \\
\hline Lime3 & $85.1 \pm 29 \mathrm{de}$ & $55 \pm 0$ & $60=$ & $4 \pm 1 \mathrm{a}$ & $7 \mathrm{a}$ & 1.38 & $3 \pm 2 d$ & & $3 b c$ \\
\hline 4 & 8 & $55 \pm$ & 50 & $3 \pm 0$ & 1. & 1.4 & $3 \mathrm{~cd}$ & & $\pm 3 b c$ \\
\hline 5 & 73.8 & 5 & 56. & $3.77=$ & 2. & 1.4 & $3 \mathrm{c}$ & & $\pm 1 \mathrm{~d}$ \\
\hline 6 & $75.6 \pm 39 \mathrm{e}$ & $55 \pm$ & 5 & 3.33 & & $1.5=$ & $\pm 3 \mathrm{c}$ & & $\pm 2 \mathrm{c}$ \\
\hline$\underline{L}$ & 6 & 50 & 5 & $3 \pm 0.5 \mathrm{c}$ & & 1.2 & $3 \pm 3 \mathrm{~cd}$ & & \\
\hline e8 & $106.1 \pm 21 b c$ & $59 \pm 0.8 \mathrm{ab}$ & $60 \pm$ & $3.72 \pm 0.7 \mathrm{ab}$ & 1. & $2 \pm 0$. & & & $9.81 \pm 3 b$ \\
\hline e9 & $80.3 \pm 23 \mathrm{de}$ & $55 \pm 0.8 \mathrm{bc}$ & 52.5 & $3.22 \pm 0.6 b c$ & $4 \mathrm{~b}$ & $1.4 \pm$ & $9.33 \pm 3 c$ & $0.9 \mathrm{~b}$ & $8.41 \pm 3 b c$ \\
\hline $\mathrm{e} 10$ & $111 \pm 24 b$ & $60 \pm 0.9 \mathrm{a}$ & $60 \pm$ & $3.38 \pm 0.5 b$ & 1. & $1.5 \pm$ & $3 \mathrm{~cd}$ & & $7.66 \pm 2 c$ \\
\hline e11 & $84.6 \pm 26 \mathrm{de}$ & $55 \pm 0.4 \mathrm{bc}$ & $36.3 \pm$ & $3.63 \pm 0.6 \mathrm{ab}$ & & $1.14 \pm 0.4 \mathrm{~cd}$ & $8.13 \pm 2 \mathrm{~d}$ & $8 \mathrm{ab}$ & $9.58 \pm 3 b$ \\
\hline Lime12 & $56.0 \pm 13 f$ & $50 \pm 0.5 \mathrm{~d}$ & $50 \pm 0$ & $3 \pm 0.6 \mathrm{c}$ & $1.57 \pm 0$. & $1 \pm 0.2 \mathrm{~d}$ & $10 \pm 4 b$ & & $8.25 \pm 3 b c$ \\
\hline e13 & $47.4 \pm 12 \mathrm{f}$ & $45 \pm 0.4 \mathrm{e}$ & $50 \pm 0.2 d$ & $3.2 \pm 0.6 \mathrm{c}$ & $1.71 \pm$ & $1.33 \pm 0.3$ & $8.66 \pm 3 \mathrm{~cd}$ & 3.7 & $6.12 \pm 1 \mathrm{de}$ \\
\hline 14 & $56.6 \pm 10 \mathrm{f}$ & $50 \pm 0.3 \mathrm{~d}$ & 32.6 & $3.2 \pm 0.4 \mathrm{c}$ & & $2 \pm 0$ & $3 \pm 3 \mathrm{~cd}$ & & $7.88 \pm 2 \mathrm{c}$ \\
\hline e15 & $82.4 \pm 30 \mathrm{de}$ & $50 \pm 0.6 \mathrm{~d}$ & $55 \pm 0.4 \mathrm{c}$ & $3.42 \pm 0.5 b$ & $2 \pm 0.4 \mathrm{~b}$ & $1 \pm 0.2 \mathrm{~d}$ & $8.66 \pm 3 \mathrm{~cd}$ & $2.6 \pm 0.6 \mathrm{~d}$ & $6.61 \pm 1 d$ \\
\hline & $41.6 \pm 12 \mathrm{~h}$ & $55 \pm 0.4 \mathrm{bc}$ & $50 \pm 0.4 \mathrm{~d}$ & $3.16 \pm 0.4 \mathrm{bc}$ & $2 \pm 0.5 \mathrm{~b}$ & $1 \pm 0.1 \mathrm{~d}$ & $8.88 \pm 3 \mathrm{~cd}$ & $3.11 \pm 0.7 \mathrm{~cd}$ & $7.75 \pm 3 c$ \\
\hline e17 & $41.2 \pm 16 \mathrm{~h}$ & $50 \pm 0.5 \mathrm{~d}$ & $46.6 \pm 0.3 \mathrm{e}$ & $2.57 \pm 0.3 \mathrm{~cd}$ & $1.37 \pm 0.2 \mathrm{e}$ & $1.4 \pm 0.3 \mathrm{bc}$ & $8.8 \pm 3 \mathrm{~cd}$ & $3.93 \pm 0.7 \mathrm{c}$ & $5.83 \pm 1 \mathrm{e}$ \\
\hline ime18 & $53.8 \pm 28 \mathrm{fg}$ & $46.6 \pm 0.2 \mathrm{ef}$ & $50 \pm 0.3 \mathrm{~d}$ & $3.66 \pm 0.8 \mathrm{ab}$ & $2 \pm 0.4 \mathrm{~b}$ & $1.57 \pm 0.4 \mathrm{~b}$ & $8 \pm 2 d$ & $3.26 \pm 0.7 \mathrm{~cd}$ & $7 \pm 2 \mathrm{c}$ \\
\hline Lime19 & $47 \pm 14 \mathrm{~g}$ & $42.5 \pm 0.8 \mathrm{e}$ & $50 \pm 0.2 d$ & $2.75 \pm 0.1 \mathrm{~cd}$ & $1.2 \pm 0.1 \mathrm{f}$ & $1 \pm 0.1 \mathrm{~d}$ & $8.8 \pm 3 \mathrm{~cd}$ & $3 \pm 0.7 \mathrm{~cd}$ & $7.5 \pm 2 \mathrm{c}$ \\
\hline Lime20 & $90.6 \pm 21 \mathrm{de}$ & $56.9 \pm 0.5 b$ & $60 \pm 1 \mathrm{ab}$ & $3.6 \pm 0.6 \mathrm{ab}$ & $1.83 \pm 0.4 \mathrm{c}$ & $1.25 \pm 0.3 \mathrm{c}$ & $9.2 \pm 3 c$ & $2.2 \pm 0.5 \mathrm{de}$ & $9.66 \pm 3 b$ \\
\hline
\end{tabular}

Note: Data are averaged \pm SD; values in each column followed by the same letters are not significantly different according to Duncan's multiplerange test $(\mathrm{p}<0.05)$. 
Table 3. Mean values and significance degree of differences between lime genotypes for juice parameters

\begin{tabular}{|c|c|c|c|c|c|c|c|}
\hline Genotypes & $\begin{array}{c}\text { Weight } \\
(\mathrm{g})\end{array}$ & $\begin{array}{l}\text { Volume } \\
(\mathrm{ml})\end{array}$ & $\begin{array}{l}\text { Density } \\
\left(\mathrm{g} \cdot \mathrm{ml}^{-1}\right)\end{array}$ & $\begin{array}{l}\text { TA } \\
(\%) \\
\end{array}$ & $\begin{array}{c}\text { TSS } \\
\left({ }^{\circ} \text { Brix }\right)\end{array}$ & $\mathrm{pH}$ & $\begin{array}{c}\text { Vit. C } \\
\left(\mathrm{mg} \cdot 100 \mathrm{mg}^{-1}\right)\end{array}$ \\
\hline LimePal1 & $128.6 \pm 40 \mathrm{~h}$ & $75 \pm 8 d$ & $101.6 \mathrm{bc}$ & $0.09 \mathrm{c}$ & $11 \pm 2 \mathrm{a}$ & $5.7 \pm 0.1 \mathrm{~b}$ & $48.8 \pm 4 \mathrm{a}$ \\
\hline LimePal2 & $349.3 \pm 90 \mathrm{a}$ & $150 \pm 12 \mathrm{a}$ & $101.3 \mathrm{c}$ & $0.07 \mathrm{de}$ & $9.4 \pm 2 b$ & $5.7 \pm 0.1 \mathrm{~b}$ & $37.7 \pm 3 d$ \\
\hline LimeBirs & $184.3 \pm 80 \mathrm{~d}$ & $117.5 \pm 10 \mathrm{~b}$ & $101 \mathrm{bc}$ & $0.09 \mathrm{c}$ & $8.3 \pm .5 \mathrm{~cd}$ & $5.5 \pm 0.1 \mathrm{~b}$ & $35.7 \pm 3 d$ \\
\hline Lime1 & $139.3 \pm 50 \mathrm{~g}$ & $90 \pm 9 c$ & $102 \mathrm{ab}$ & $0.1 b c$ & $7.5 \pm 1 \mathrm{~d}$ & $5.1 \pm .01 \mathrm{~d}$ & $30.9 \pm 2 \mathrm{de}$ \\
\hline Lime2 & $156.3 \pm 60 \mathrm{f}$ & $100 \pm 9 b c$ & $100.6 \mathrm{~cd}$ & $0.08 \mathrm{~cd}$ & $8.5 \pm 1 b c$ & $5.9 \pm 0.2 b$ & $28.8 \pm 2 \mathrm{ef}$ \\
\hline Lime3 & $159.6 \pm 60 \mathrm{f}$ & $75 \pm 12 \mathrm{~cd}$ & $100.6 \mathrm{~cd}$ & $0.08 \mathrm{~cd}$ & $7.8 \pm 1 \mathrm{~d}$ & $5.8 \pm 0.1 \mathrm{ab}$ & $27.9 \pm 2 \mathrm{ef}$ \\
\hline Lime4 & $186 \pm 85 \mathrm{~d}$ & $70 \pm 10 \mathrm{~d}$ & $100.6 \mathrm{~cd}$ & $0.1 \mathrm{bc}$ & $7.4 \pm 1 \mathrm{~d}$ & $5.5 \pm 0.1 \mathrm{~b}$ & $26.2 \pm 1 \mathrm{f}$ \\
\hline Lime5 & $140.6 \pm 50 \mathrm{~g}$ & $60 \pm 7 \mathrm{de}$ & $102.3 \mathrm{ab}$ & $0.09 \mathrm{c}$ & $8.5 \pm 1 b c$ & $5.6 \pm 0.1 \mathrm{~b}$ & $31.5 \pm 2 d$ \\
\hline Lime6 & $119.3 \pm 50 \mathrm{~h}$ & $100 \pm 10 \mathrm{bc}$ & $101.3 \mathrm{bc}$ & $0.08 \mathrm{~cd}$ & $8.8 \pm 1.5 \mathrm{bc}$ & $5.6 \pm 0.1 \mathrm{~b}$ & $32.7 \pm 2 d$ \\
\hline Lime7 & $112.3 \pm 50 \mathrm{~h}$ & $65 \pm 5 \mathrm{de}$ & $102.6 \mathrm{ab}$ & $0.09 \mathrm{c}$ & $8.7 \pm 1 \mathrm{bc}$ & $5.6 \pm 0.1 \mathrm{~b}$ & $33.3 \pm 3 d$ \\
\hline Lime8 & $205 \pm 85 b$ & $152 \pm 10 \mathrm{a}$ & $101.3 \mathrm{bc}$ & $0.08 \mathrm{~cd}$ & $7.3 \pm 0.5 \mathrm{de}$ & $5.3 \pm 0.1 b c$ & $48.9 \pm 4 a$ \\
\hline Lime9 & $163 \pm 6 \mathrm{ef}$ & $75 \pm 9 d$ & $101 b c$ & $0.06 \mathrm{e}$ & $7.4 \pm 0.5 \mathrm{de}$ & $5.8 \pm 0.1 \mathrm{~b}$ & $30.6 \pm 2 \mathrm{de}$ \\
\hline Lime10 & $230.6 \pm 80 \mathrm{~b}$ & $90 \pm 10 \mathrm{c}$ & $101.3 \mathrm{bc} 3$ & $0.09 \mathrm{c}$ & $8.2 \pm 1 \mathrm{~cd}$ & $5.6 \pm 0.1 \mathrm{~b}$ & $32.7 \pm 2 \mathrm{~d}$ \\
\hline Lime11 & $185 \pm 80 \mathrm{~d}$ & $85 \pm 9 c$ & $102 \mathrm{ab}$ & $0.11 \mathrm{ab}$ & $9.1 \pm 2 b$ & $5.84 \pm 0.1 b$ & $30.4 \pm 2 \mathrm{de}$ \\
\hline Lime12 & $119.6 \pm 30 \mathrm{i}$ & $70 \pm 9 d$ & $100.33 b c$ & $0.08 \mathrm{~cd}$ & $8.3 \pm 1 \mathrm{~cd}$ & $5.9 \pm 0.2 b$ & $45.7 \pm 3 b$ \\
\hline Lime13 & $94 \pm 40 \mathrm{k}$ & $55 \pm 3 f$ & $101.3 \mathrm{bc}$ & $0.12 \mathrm{a}$ & $9.4 \pm 2 b$ & $6.05 \pm 0.2 \mathrm{~b}$ & $28.8 \pm 2 \mathrm{ef}$ \\
\hline Lime14 & $105.3 \pm 4 \mathrm{i}$ & $67 \pm$ dde & $101 \mathrm{bc}$ & $0.09 \mathrm{c}$ & $8.6 \pm 1 b c$ & $5.77 \pm 0.1 b$ & $34.3 \pm 3 d$ \\
\hline Lime15 & $173 \pm 7 \mathrm{e}$ & $100 \pm 10 b c$ & $101.3 \mathrm{bc}$ & $0.1 \mathrm{bc}$ & $8.2 \pm 1 \mathrm{~cd}$ & $5.7 \pm 0.1 \mathrm{~b}$ & $32.4 \pm 2 d$ \\
\hline Lime16 & $97.6 \pm 3 \mathrm{k}$ & $100 \pm 12 b c$ & $102.6 \mathrm{ab}$ & $0.07 \mathrm{de}$ & $7 \pm 0.5 \mathrm{de}$ & $5.9 \pm 0.1 \mathrm{ab}$ & $29.3 \pm 1 \mathrm{ef}$ \\
\hline Lime17 & $102.6 \pm 4 \mathrm{i}$ & $67 \pm 5 \mathrm{de}$ & $103.6 \mathrm{a}$ & $0.1 \mathrm{bc}$ & $9.5 \pm 2 b$ & $6.3 \pm 0.1 \mathrm{a}$ & $40 \pm 3 c$ \\
\hline Lime18 & $89.6 \pm 31$ & $50 \pm 5 \mathrm{e}$ & $102 \mathrm{ab}$ & $0.1 \mathrm{bc}$ & $8.5 \pm 1.5 \mathrm{~cd}$ & $5.6 \pm 0.1 \mathrm{~b}$ & $31.1 \pm 2 \mathrm{~d}$ \\
\hline Lime19 & $77.6 \pm 1 \mathrm{~m}$ & $67.5 \pm 6 \mathrm{de}$ & $102 \mathrm{ab}$ & $0.11 \mathrm{ab}$ & $8.6 \pm 1.5 b c$ & $5.3 \pm 0.1 \mathrm{bc}$ & $27.3 \pm 2 \mathrm{ef}$ \\
\hline Lime20 & $184.6 \pm 8 \mathrm{~d}$ & $95 \pm 12 b c$ & $101 \mathrm{bc}$ & $0.1 \mathrm{bc}$ & 7.4 & $5.7 \pm 0.1 \mathrm{~b}$ & $26.8 \pm 1 \mathrm{f}$ \\
\hline
\end{tabular}

Note: See Table 2

Variation among lime species for studied quantitative traits

Table 4 describes the minimum, maximum, mean, standard deviation, and CV for each variable studied. The weight of fruit varied from $41.3 \mathrm{~g}$ (Lime16) to $157.9 \mathrm{~g}$ (LimePal 2) per fruit with a mean of $77.3 \mathrm{~g}$ per fruit. High variability between cultivars was observed for fruit weight, which is confirmed by the relatively high CV (32\%). The number of seeds per fruit varied from 1.2 (Lime3) to 5.4 (Lime8) with a mean of 3.3 and a $\mathrm{CV}$ of $35 \%$. The weight of juice was highly variable $(\mathrm{CV}=42 \%)$, ranging from 6.5 (Lime19) to 69.9 (Limpal2) with a mean of 29.9. The volume of juice varied from $50 \mathrm{ml}$ (Lime18) to $152 \mathrm{ml}$ (Lime8), with a mean of $80 \mathrm{ml}(\mathrm{CV}=32 \%)$.
These four parameters were the most discriminant between cultivars based on CVs. The fruit rind thickness $(\mathrm{CV}=21 \%)$ range from $1 \mathrm{~mm}$ (Lime6 and Lime14) to $2 \mathrm{~mm}$ (LimPal 2 and Lime3). Diameter of fruit axis $(\mathrm{CV}=19 \%)$ range from 26.19 (Lime4) to $48.9 \mathrm{mg} \cdot \mathrm{dm}^{-3}$ (LimPal2 and Lime8).

\section{Correlations among studied traits}

In order to estimate correlation between quantitative parameters based on the data measured on Tunisian limes, Pearson's correlation coefficients were estimated (Table 5). A significant correlation among several quantitative parameters was observed. Weight of fruit was significantly and positively correlated with fruit diameter $(\mathrm{r}=0.81 ; \mathrm{p} \leq 0.01)$, diameter of fruit axis $(\mathrm{r}=0.75 ; \mathrm{p} \leq 0.05)$, weight and volume of juice $(r=0.97 ; p \leq 0.01 ; r=0.62 ; p \leq 0.01$, respectively), 
fruit length $(r=0.61 ; p \leq 0.05)$, width of fruit skin $(r=0.61 ; p \leq 0.05)$, and width of epicarp at equatorial plane $(r=0.60 ; p \leq 0.05)$. Fruit diameter was significantly and positively correlated with the diameter of fruit axis $(r=0.68 ; p \leq 0.01)$ and weight of juice $(\mathrm{r}=0.84 ; \mathrm{p} \leq 0.01)$. Highly significant and positively correlations were observed between fruit skin width and width of pericarp at equatorial plane $(\mathrm{r}=0.77$; $p \leq 0.01$ ). Number of segment was significantly and positively correlated with TSS $(r=0.63 ; \mathrm{p} \leq 0.01)$; diameter of fruit axis was significantly and positively correlated with weight of juice $(r=0.75 ; p \leq 0.01)$.

Estimation of variation among qualitative traits using the Shannon-Wiener diversity index

Seed color was the most discriminant trait with four different phenotypes (Table 6). Similarly, fruit skin color, fruit surface texture, adherence of albedo to pulp, adherence of segment walls, vesicle length and thickness, fruit axis, and cotyledon color were also more discriminant compared with all the other parameters. Uniformity of pulp color and cross-section shape of axis were monomorphic for all the accessions studied (Table 6). H' ranged from 0 for both cross-section shape and pulp color uniformity to 0.98 for both thickness of segment walls and vesicle thickness (Table 6) with a mean value of 0.61 . Moreover, other parameters showed high values of $H^{\prime}$ : fruit skin (epicarp) color $\left(H^{\prime}=0.96\right)$, shape of fruit base $\left(\mathrm{H}^{\prime}=0.93\right)$, seed color $\left(\mathrm{H}^{\prime}=0.84\right)$, pulp (flesh) color $\left(\mathrm{H}^{\prime}=0.82\right)$, and fruit surface texture $\left(H^{\prime}=0.8\right)$. According to the Shannon diversity index, we assume that shape of fruit apex, fruit skin epicarp color, fruit surface texture, thickness of segment walls, pulp (flesh color), vesicle thickness, seed shape, and seed color were the most discriminant qualitative parameters. Pulp (flesh color), fruit skin epicarp color, and fruit surface texture are definitely used as selection criteria throughout the supply and consumption chain. It is well known that genetics, environment, and cultural practices interact to define the eventual main fruit traits (weight, diameter, length, and width of skin).

\section{Principal component analysis}

PCA was performed based on fruit and juice quantitative parameters. The results showed that $60.3 \%$ of the total variability is accounted for the first three principal components (PCs). The first two PCs account $35.5 \%$ and $15.5 \%$ of the total variability (Fig. 2 and Table 7). The PC1 positively correlated with weight and diameter of fruit, diameter of axis, and weight of juice. The PC2 positively correlated with fruit rind (mesocarp) thickness, number of segments, and vitamin $\mathrm{C}$ content. The projection of lime cultivars in the plan 1-2 of the PCA allows the discrimination of the species $C$. limettioides and Lime8 from the other genotype (Fig. 2). Regarding C. latifolia and C. limetta, we did not observe any significant discrimination. Accessions from these cultivars were grouped together. Regarding TSS and content of vitamin C, both LimPall and LimPal2 exhibited the highest values. Moreover, PCA has also distinguished $C$. limettioides (LimPal 1 and LimPal 2) and Lime 8 from all the other cultivars. Lime8 genotype, which belongs to $C$. limetta species, is characterized by large fruit. For this reason, it has been clustered with genotypes LimPall and LimPal2, which belongs to $C$. limettioides species. This species can be selected for breeders in order to improve fruit size (weight and diameter of fruit) and yield of juice. On the basis of the same descriptors of Citrus (IPGRI 1999), similar findings were recorded, referring to Saddoud Debbabi et al. (2013) for the main parameters correlated with the first axis of PCA (weight, diameter, and length of fruit). Phenotypic characterization have shown their efficiency for many crops, such as carrot (Mezghani et al. 2014) and wheat (Mengistu et al. 2015), and for many fruit trees such as fig (Saddoud et al. 2008; Gaaliche et al. 2012), olive (Hannachi et al. 2008), apricot (Ruiz \& Egea 2008), apple (Mratinić \& Fotirić Akšić 2011), and cornelian cherry (Moradi et al. 2019). This evaluation is necessary to achieve the developmental program and genetic improvement of the lime species. The outcomes of this study will be very useful for Tunisian Gene Bank and for a good identification and documentation of Citrus genetic resources. Although pomological characterization is low cost method and has many advantages, it remains limited in the number of characters and is limited in use. The characterization could be improved through the involvement of molecular markers, for example Simple Sequence Repeat (SSR) that allows the study of molecular diversity and the establishment of fingerprints of the cultivars studied. 


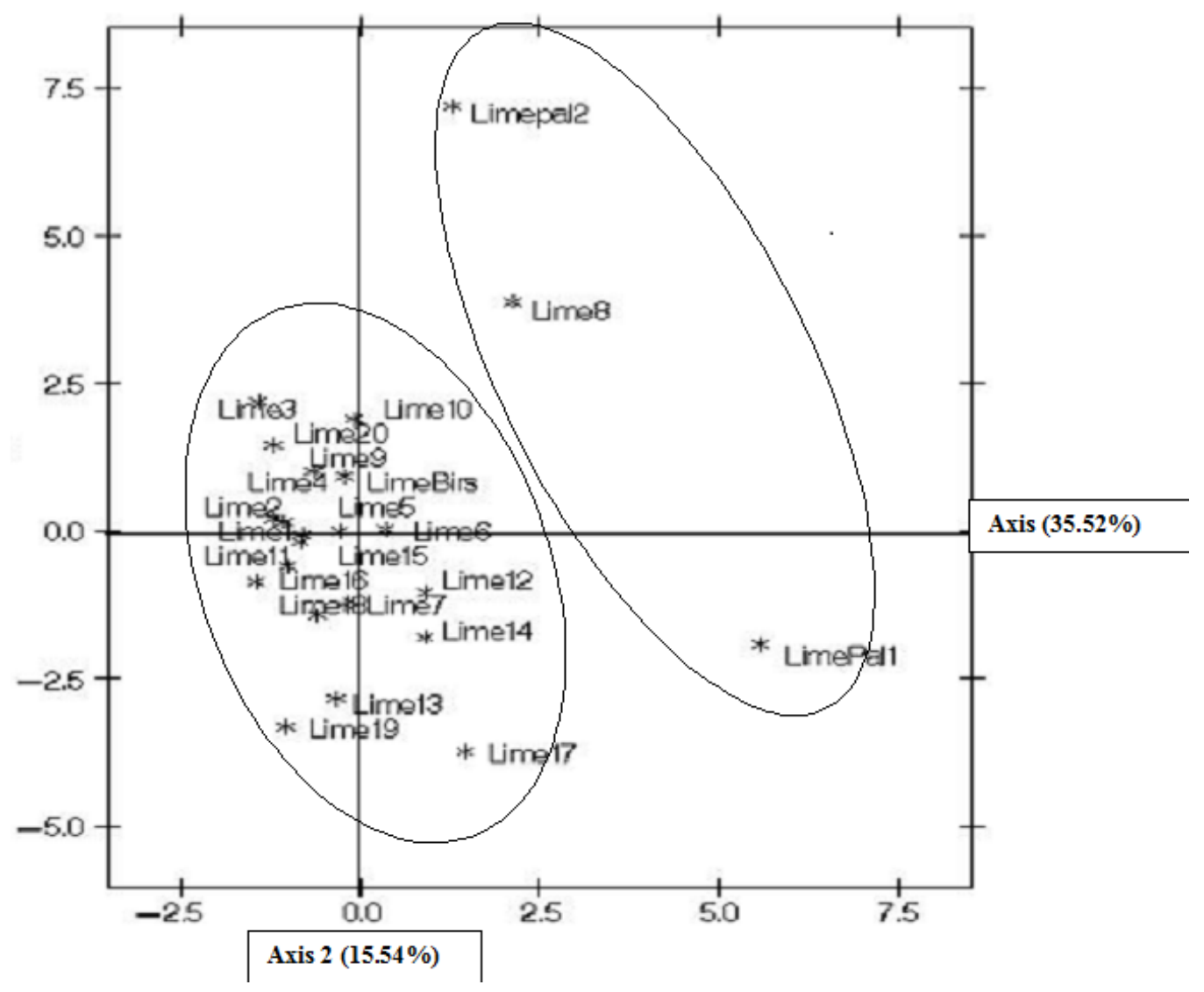

Fig. 2. PCA biplot of lime cultivars based on quantitative traits

Table 4. Descriptive statistics of quantitative traits studied for Tunisian lime genotypes

\begin{tabular}{lccccc}
\hline \multicolumn{1}{c}{ Variable } & Minimum & Maximum & Mean & Standard deviation & CV $(\%)$ \\
\hline Weight $(\mathrm{g})$ & 41.26 & 157.9 & 77.3 & 25.1 & 32 \\
\hline Fruit diameter $(\mathrm{mm})$ & 42.5 & 65 & 52.8 & 52 & 9 \\
\hline Fruit length $(\mathrm{mm})$ & 32.6 & 66.9 & 51.7 & 74 & 14 \\
\hline Width of fruit skin $(\mathrm{mm})$ & 2.5 & 4.0 & 3.3 & 0.3 & 11 \\
\hline Width of epicarp at equatorial plane $(\mathrm{mm})$ & 1.2 & 2.7 & 1.8 & 0.34 & 18 \\
\hline Fruit rind $($ mesocarp) thickness $(\mathrm{mm})$ & 1.0 & 2.0 & 1.3 & 0.3 & 21 \\
\hline Number of segments & 8 & 16.4 & 9.1 & 1.6 & 18 \\
\hline Number of seeds & 1.2 & 5.4 & 3.2 & 1.1 & 35 \\
\hline Diameter of fruit axis $(\mathrm{mm})$ & 583 & 1340 & 817 & 164 & 20 \\
\hline Weight of juice $(\mathrm{g})$ & 6.5 & 69.8 & 29.9 & 12.71 & 42 \\
\hline Volume of juice $(\mathrm{ml})$ & 50 & 152 & 80 & 26 & 32 \\
\hline Density of juice $\left(\mathrm{g} \cdot \mathrm{ml}^{-1}\right)$ & 100.3 & 103.6 & 101.5 & 0.8 & 0.7 \\
\hline TSS $\left({ }^{\circ}\right.$ Brix) & 7.00 & 11 & 8.4 & 0.9 & 10 \\
\hline pH & 5.1 & 6.2 & 5.7 & 0.2 & 4 \\
\hline TA $(\%)$ & 0.06 & 0.1 & 0.09 & 0.01 & 15 \\
\hline Vitamin C $\left(\mathrm{mg} \cdot 100 \mathrm{mg}^{-1}\right)$ & 26.2 & 48.9 & 33.5 & 6.57 & 19 \\
\hline
\end{tabular}




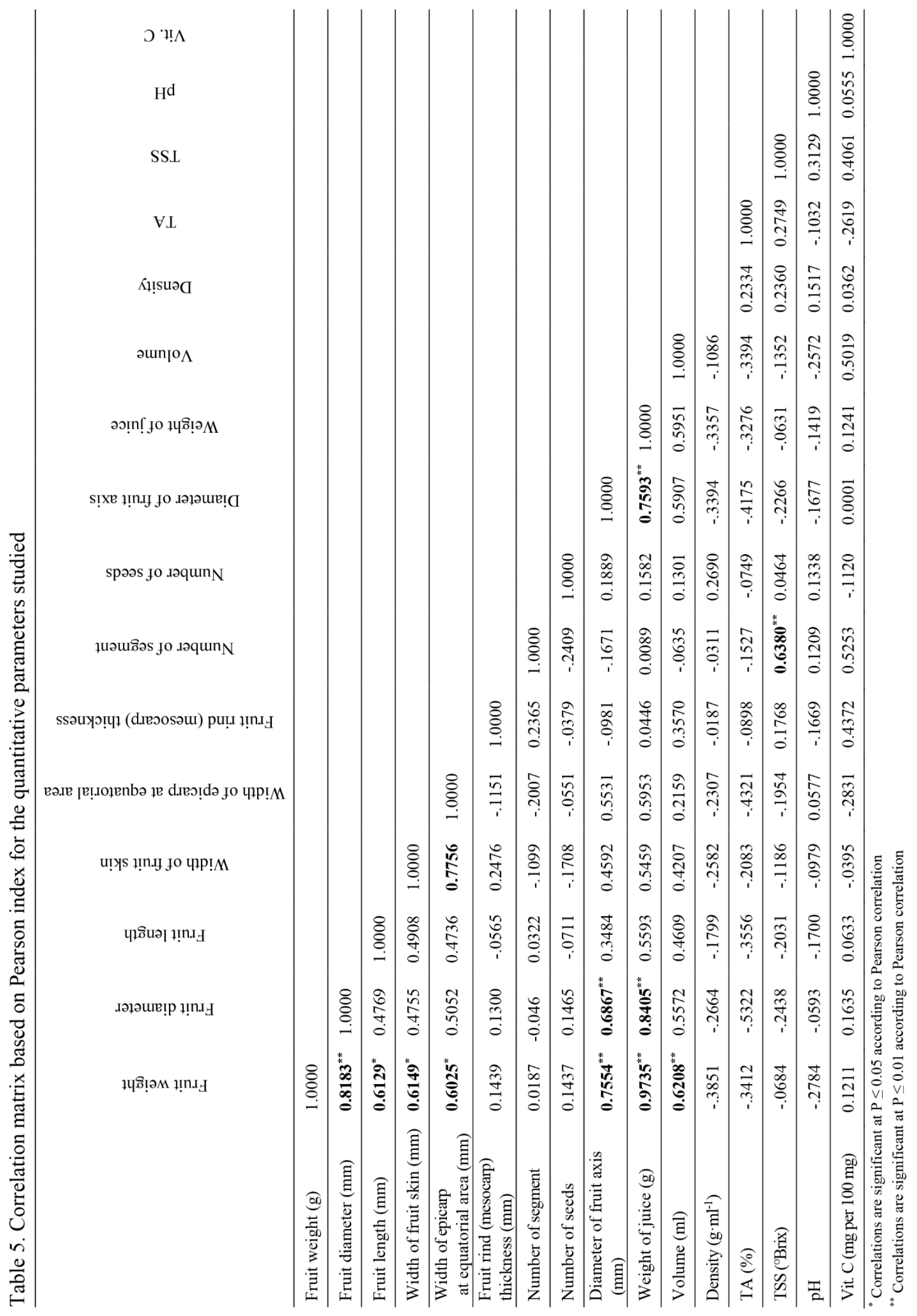


Table 6. Qualitative descriptors used for estimating pomological trait diversity in lime genotypes, their number of classes, proportion (\%) of occurrence of each class, and estimated phenotypic diversity index (H') for each trait

\begin{tabular}{|c|c|c|c|c|}
\hline Pomological trait & $\begin{array}{c}\text { Observed } \\
\text { phenotypic class }\end{array}$ & Class* & $\begin{array}{l}\text { Proportion } \\
\quad(\%)\end{array}$ & $\begin{array}{l}\text { Shannon-Wiener } \\
\text { index }\left(\mathrm{H}^{\prime}\right)\end{array}$ \\
\hline \multirow{2}{*}{ Fruit shape } & \multirow{2}{*}{2} & 1 spheroid & 96 & \multirow{2}{*}{0.24} \\
\hline & & 2 ellipsoid & 4 & \\
\hline \multirow{2}{*}{ Shape of fruit apex } & \multirow{2}{*}{2} & 1 mammiform & 96 & \multirow{2}{*}{0.24} \\
\hline & & 3 rounded & 4 & \\
\hline \multirow{2}{*}{ Shape of fruit base } & \multirow{2}{*}{2} & 2 convex & 65 & \multirow{2}{*}{0.93} \\
\hline & & 3 truncate & 35 & \\
\hline \multirow{3}{*}{ Fruit skin (epicarp) color } & \multirow{3}{*}{3} & 2 green-yellow & 35 & \multirow{3}{*}{0.96} \\
\hline & & 4 yellow & 22 & \\
\hline & & 5 dark yellow & 43 & \\
\hline \multirow{3}{*}{ Fruit surface texture } & \multirow{3}{*}{3} & 1 smooth & 30 & \multirow{3}{*}{0.8} \\
\hline & & 2 rough & 9 & \\
\hline & & 4 pitted & 61 & \\
\hline \multirow{3}{*}{$\begin{array}{l}\text { Adherence of albedo (mesocarp) } \\
\text { to pulp (endocarp) }\end{array}$} & \multirow{3}{*}{3} & 3 weak & 4 & \multirow{3}{*}{0.75} \\
\hline & & 5 medium & 44 & \\
\hline & & 7 strong & 52 & \\
\hline \multirow{3}{*}{$\begin{array}{l}\text { Adherence of segment walls } \\
\text { to each other }\end{array}$} & \multirow{3}{*}{3} & 3 weak & 4 & \multirow{3}{*}{0.72} \\
\hline & & 5 medium & 35 & \\
\hline & & 7 strong & 61 & \\
\hline \multirow{3}{*}{ Thickness of segment walls } & \multirow{3}{*}{3} & 3 thin & 35 & \multirow{3}{*}{0.98} \\
\hline & & 5 medium & 39 & \\
\hline & & 7 thick & 26 & \\
\hline \multirow{3}{*}{ Fruit axis } & \multirow{3}{*}{3} & 1 solid & 4 & \multirow{3}{*}{0.49} \\
\hline & & 2 semi-hollow & 83 & \\
\hline & & 3 hollow & 13 & \\
\hline Cross-section shape of axis & 1 & 1 round & 100 & 0 \\
\hline \multirow{2}{*}{ Pulp (flesh) color } & \multirow{2}{*}{2} & 2 green & 26 & \multirow{2}{*}{0.82} \\
\hline & & 3 yellow & 74 & \\
\hline
\end{tabular}




\begin{tabular}{|c|c|c|c|c|}
\hline Pulp color uniformity & 1 & 1 uniform & 100 & 0 \\
\hline \multirow{2}{*}{ Pulp firmness } & \multirow{2}{*}{2} & 5 intermediate & 9 & \multirow{2}{*}{0.43} \\
\hline & & 7 firm & 91 & \\
\hline \multirow{3}{*}{ Vesicle length } & \multirow{3}{*}{3} & 3 short & 5 & \multirow{3}{*}{0.33} \\
\hline & & 5 medium & 4 & \\
\hline & & 7 long & 91 & \\
\hline \multirow{3}{*}{ Vesicle thickness } & \multirow{3}{*}{3} & 3 thin & 35 & \multirow{3}{*}{0.98} \\
\hline & & 5 medium & 26 & \\
\hline & & 7 thick & 39 & \\
\hline \multirow{2}{*}{ Seed shape } & \multirow{2}{*}{2} & 2 clavate & 74 & \multirow{2}{*}{0.82} \\
\hline & & 4 ovoid & 26 & \\
\hline \multirow{2}{*}{ Seed surface } & \multirow{2}{*}{2} & 1 smooth & 78 & \multirow{2}{*}{0.76} \\
\hline & & 2 wrinkled & 22 & \\
\hline \multirow{4}{*}{ Seed color } & \multirow{4}{*}{4} & 2 cream & 13 & \multirow{4}{*}{0.84} \\
\hline & & 3 yellowish & 26 & \\
\hline & & 4 green & 52 & \\
\hline & & 5 green (medium) & 9 & \\
\hline \multirow{4}{*}{ Cotyledon color } & \multirow{4}{*}{4} & 1 white & 13 & \multirow{4}{*}{0.65} \\
\hline & & 2 light yellow-cream & 4 & \\
\hline & & 3 light green & 13 & \\
\hline & & 5 green (medium) & 70 & \\
\hline
\end{tabular}

*observed class defined based on IPGRI Manual (1999)

Table 7. Eigenvectors, the main eigenvalues, and variation in percentage of the two first principal components of PCA

\begin{tabular}{lll}
\hline \multicolumn{1}{c}{ Principal components } & \multicolumn{1}{c}{ PC1 } & \multicolumn{1}{c}{ PC2 } \\
\hline Cumulative (\%) & 35.52 & 51.06 \\
\hline Proportion (\%) & 35.52 & 15.54 \\
\hline \multirow{3}{*}{ Eigenvalues } & Weight of fruit $(\mathrm{g})(+0.39)$ & Fruit rind (mesocarp) thickness $(\mathrm{mm})(+0.37)$ \\
& Diameter of fruit $(\mathrm{mm})(+0.36)$ & Number of segments $(+0.49)$ \\
& Diameter of axis $(\mathrm{mm})(+0.34)$ & Vitamin $\mathrm{C} \mathrm{mg} \cdot 100 \mathrm{~g}^{-1}(+0.55)$ \\
& Weight of juice $(\mathrm{g})(+0.38)$ & \\
\hline
\end{tabular}




\section{CONCLUSION}

The accessions Lime8, LimePal2, and Lime10 had good genetic potential for the important characters: weight and diameter of fruit, diameter of axis, and weight of juice. The collected data point to the need to protect endangered lime species and may help further efforts to portray the diversity of this species in Tunisia.

\section{REFERENCES}

Barrett H.C., Rhodes A.M. 1976. A numerical taxonomic study of affinity relationships in cultivated Citrus and its close relatives. Systematic Botany 1: 105136. DOI: $10.2307 / 2418763$.

Blondel L. 1978. Classification botanique des espèces du genre Citrus. Fruits 33(11): 695-720. [in French]

Curk F., Ollitrault F., Garcia-Lor A., Luro A., Navarro L., Ollitrault P. 2016. Phylogenetic origin of limes and lemons revealed by cytoplasmic and nuclear markers. Annals of Botany 117(4): 565-583. DOI: 10.1093/aob/mcw005.

DGPA 2016. Direction Générale de la Production Agricole. Tunisian Ministry of Agriculture. www.agriculture.tn (accessed June 2016)

Eticha F., Bekele E., Belay G., Börner B. 2005. Phenotypic diversity in durum wheat collected from Bale and Wello regions of Ethiopia. Plant Genetic Resources 3(1): 35-43. DOI: 10.1079/pgr200457.

Gaaliche B, Saddoud O., Mars M. 2012. Morphological and pomological diversity of fig (Ficus carica L.) cultivars in Northwest of Tunisia. ISRN Agronomy, Article ID 326461, 9 p. DOI: 10.5402/2012/326461.

Hannachi H., Breton C., Msallem M., Ben El Hadj S., El Gazzah M., Bervillé A. 2008. Differences between native and introduced olive cultivars as revealed by morphology of drupes, oil composition and SSR polymorphisms: A case study in Tunisia. Scientia Horticulturae 116: 280-290. DOI: 10.1016/j.scienta.2008.01.004.

IPGRI 1999. Descriptors for citrus. International Plant Genetic Resources Institute, Italy, 66 p.

Krueger R.R., Navarro L. 2007. Citrus germplasm resources. In: Khan I.A. (Ed.), Citrus genetics, breeding and biotechnology. CAB International, pp. 45140. DOI: 10.1079/9780851990194.0045.

Kumar S., Jena S.N., Nair N.K. 2010. ISSR polymorphism in Indian wild orange (Citrus indica Tanaka, $\mathrm{Ru}$ taceae) and related wild species in North-east India. Scientia Horticulturae 123: 350-359. DOI: 10.1016/j.scienta.2009.10.008.
Mabberley D.J. 2008. Mabberley's plant-book: A portable dictionary of plants, their classifications, and uses, 3rd ed. Cambridge University Press, UK, 1021 p.

Mengistu D.K., Kiros A.Y., Pè M.E. 2015. Phenotypic diversity in Ethiopian durum wheat (Triticum turgidum var. durum) landraces. Crop Journal 3: 190199. DOI: 10.1016/j.cj.2015.04.003.

Mezghani N., Zaouali I., Bel Amri W., Rouz S., Simon P.W., Hannachi C. et al. 2014. Fruit morphological descriptors as a tool for discrimination of Daucus L. germplasm. Genetic Resources and Crop Evolution 61: 499-510. DOI: 10.1007/s10722-013-0053-6.

Moore G.A. 2001. Oranges and lemons: clues to the taxonomy of Citrus from molecular markers. Trends in Genetics 17: 536-540. DOI: 10.1016/s01689525(01)02442-8.

Moradi Y., Khadivi A., Salehi-Arjmand H. 2019. Morphological and pomological characterizations of cornelian cherry (Cornus mas L.) to select the superior accessions. Scientia Horticulturae 249: 208218. DOI: 10.1016/j.scienta.2019.01.039.

Mratinić E., Fotirić Akšić M. 2011. Evaluation of phenotypic diversity of apple (Malus sp.) germplasm through the principle component analysis. Genetika 43(2): 331-340. DOI: 10.2298/gensr1102331m.

Nicolosi E., Deng Z.N., Gentile A., La Malfa S., Continella G., Tribulato E. 2000. Citrus phylogeny and genetic origin of important species as investigated by molecular markers. Theoretical and Applied Genetics 100: 1155-1166. DOI: 10.1007/s001220051419.

Ruiz D., Egea J. 2008. Phenotypic diversity and relationships of fruit quality traits in apricot (Prunus armeniaca L.) germplasm. Euphytica 163(1): 143-158. DOI: 10.1007/s10681-007-9640-y.

Saddoud O., Baraket G., Chatti K., Trifi M., Marrakchi M., Salhi-Hannachi A., Mars M. 2008. Morphological variability of fig (Ficus carica L.) cultivars. International Journal of Fruit Science 8: 35-51. DOI: 10.1080/15538360802365921.

Saddoud Debbabi O., Bouhlal R., Abdelaali N., Mnasri S., Mars M. 2013. Pomological study of sweet orange (Citrus sinensis L. Osbeck) cultivars from Tunisia. International Journal of Fruit Science 13: 274-284. DOI: $10.1080 / 15538362.2012 .679186$.

Scora R.W. 1975. On the history and origin of citrus. Bulletin of the Torrey Botanical Club 102: 369-375. DOI: $10.2307 / 2484763$.

Snoussi H., Duval M.F., Garcia-Lor A., Belfalah Z., Froelicher Y., Risterucci A.M. et al. 2012. Assessment of the genetic diversity of the Tunisian citrus rootstock germplasm. BMC Genetics 13; 16, 12 p. DOI: 10.1186/1471-2156-13-16. 
Sthapit B., Rana R., Subedi A., Gyawali S., Bajracharya J., Chaudhary P. et al. 2012. Participatory four-cell analysis (FCA) for understanding local crop diversity. In: Sthapit B., Shrestha P., Upadhyay M. (Eds.), On-farm management of agricultural biodiversity in Nepal. Good Practices, revised edition, pp. 13-16. NARC/LI-BIRD/Bioversity International, Nepal.
Swingle W.T., Reece P.C. 1967. The botany of citrus and its wild relatives. In: Reuther W., Batchelor L.D., Webber H.J. (Eds.), The citrus industry, vol. 1. History, world distribution, botany and varieties, revised edition. University of California Press, USA, pp. 190-430.

Tanaka T. 1977. Fundamental discussion of citrus classification. Studia Citrologica 14: 1-6. [in Japanese] 